\title{
Statistical and Social Inquiry Society of Ireland
}

\section{The Social Geography of Belfast}

\author{
By Dr. Emrys Jones, Department of Geography, Q.U.B.
}

\section{(Read before the Society in Belfast on Friday 13th November, 1953.)}

The main task of the social geographer is to analyse the relationship between social groups and their environment and to identify the regional differentiation of such relationships. ${ }^{1}$ In a town or city the relationships are closely interwoven because even the physical environment is mostly man-made, and is itself the result of social activity. A man living in Belfast may catch a glimpse of Cave Hill or the Castlereagh Hills on his way to work in the morning, but he is constantly confronted with asphalt roads and tramlines, with houses and factories, and he is more aware of his fellow-men than he is of any other member of the animal kingdom. I am using the word "environment" to mean "total environment" in this case, i.e., physical and social, natural and man-made.

This study of inter-relationships is a complex aspect of a problem which has always been central in geography ; but instead of analysing, say, the adaptation of the Bushman to the dry scrub lands on the rim of the Kalahari Desert, we want to know why, for example, the Soho district of London is now the centre of Southern European immigrant groups, or why the upper classes which once lived in Soho Square were driven out to the Hampstead suburbs. We want to know to what extent social groups reflect the urban environment and to what extent they fashion it. The interplay is so close that it is for analysis only that the various factors can be abstracted and dealt with in isolation. But the geographer to-day must go much further than his usually allotted task of examining the sites of towns or studying their growth and the reasons for it: he must map its land-use in much the same way as the Land Utilisation Survey has mapped the farmlands of rural Britain, he must describe the spatial aspects of groups, their activities and their institutions, and he must tackle the problem of their inter-relatedness.

Urban studies have in the main tended to interest two types of people: firstly the town planners, who have naturally been more concerned with the physical framework, townscape and streets and houses: secondly the sociologists-though we must remember such giants as Geddes and Mumford, who comfortably straddled both worlds. If the planners have at vimes been guilty of under-estimating the social content of their work they are not wholly to blame-the body of information needed in such work is lamentably small, and it is not their primary task to collect it. The sociologists, on the other hand, after the magnificent impetus given to them at Chicago

'For a discussion of the concept of " social geography," see Watson, J. W.The Sociological Aspects of Geography in Geography in the Twentieth Century (Ed. Griffith Taylor), pp. 463-484. London, 1951. 
by Parks and Burgess, have tended to emphasise group studies with little reference to environment ; their feet sometimes leave the ground ; the frame of reference becomes social structure pure and simple. All they need to define urban standards, and even to compare cities, they find in analysis of social data only, so that degree of urbanisation, for example, can be measured in terms of the number of women in the labour force, or in fertility rates.

The social geographer is interested in both aspects. To the analysis he can contribute his technique of mapping and probing concomitant distributions; he can define physical and social regions: if possible he must determine causal sequences in related factors. On the physical side he can collect and classify his own data, but I must again stress the lack of available comparable social data. One of the great needs in a large city like Belfast is for a central bureau which could give detailed information on all social activities and demography to research workers in this field.

In Belfast, a city of nearly half a million people, the immensity of the task is so self-evident that I need not apologise for the fragmentary nature of what I am going to discuss to-night. The ultimate aim should be a synthesis of our historical, geographical and demographic knowledge. In some of these branches important beginnings have been made, as in Mr. Camblin's studies on Belfast, from the historical and planning point of view, ${ }^{2}$ and Professor Evans' studies of the site and the social geography of the city. ${ }^{3}$ An article by Professor Evans was the first in which the social history and the physical development of Belfast were synthesised, as well as being the first in which religious denominations were mapped and their distribution discussed.

As a preliminary to the small contribution which can be offered to you now, I should remind you in the first place of the frame of reference which the geographer needs-the growth of the city. I must refer you elsewhere for details of this growth, ${ }^{4}$ but here are a few of the relevant facts. Although overlooked by the bleak Antrim plateau on the one hand and fringed by the soft hills of Down on the other, Belfast is built mainly on an expanse of estuarine clay, locally known as "slob-land," between the two. This slob-land is more extensive to the west of the River Lagan and it is ringed by a slight but sharp rise-a prehistoric coast-line--leading to firmer undulating land. Up to the middle of the last century Belfast was more or less contained within this line and confined to the slob-land. The main axis of the garrison and market town which Sir Arthur Chichester founded on this level slob-land in the first decade of the 17th century was the River Farset, which until 150 years ago ran down the centre of High Street, approximately from west to east. This remained the pivot until the first quarter of the last century, when building and platting had practically covered the slob-land up to the shore line (which is still easily perceptible along North. Queen Street and at Peter's Hill). This development swung the axis north and south, York Street in the north becoming a main artery, and the south centring on the

2 Camblin, G. : The Town in Ulster, Belfast, 195 J.

${ }^{3}$ Evans, E. E., The Site of Beljast, Geography, XXII, 1937.

do. Belfast, the Site and the City, Belfast, 1944. Reprint from Ulster Journal of Archaeology (IIIrd Series) VII, 1944.

4 Jones, E., Belfast, a Survey of the City in Belfast in its Regional Setting, British Association Handbook, Belfast, 1952. 
streets around the White Linen Hall. The geometric planning in these areas, with its pleasant spaciousness, is still a marked feature of Belfast's morphology. Where the straight roads of the slob-land met the higher and firmer ground on the city's periphery they branched and meandered, probably along ancient routeways which were established in prehistoric times. At Peter's Hill one road goes north to Carrickfergus and another goes north-west to climb the scarp to Crumlin. To the south-west runs the Falls Road, again penetrating the western hinterland. The Bog Meadows are avoided and the southerm roar to Dublin is that which follows the ridge of sands and gravels which underlies Malone. This last road was later augmented by the Lisburn Road, skirting the east of the Bog Meadows. The main route across the Lagan goes towards the "Comber Gap" to Newtownards, and a branch goes north-eastward to Holywood and Bangor. It was along these main arteries that the vast sprawl of nineteenth century Belfast grew, as innocent of order or planning as the primitive routeways that it preserved.

This industrial growth of the last century, with its great increases of population, centred particularly on the tributary streams to the west of the city, the Farset, Forth and Blackstaff. Water was the earliest form of power, and the first mill in the town was on the Farset, just outside the town walls. When cotton, and later linen manufacturing was established on steam power, water was still indispensable, and the factories developed on these rivers, stretching westward towards the plateau. Later still auxiliary industries such as machine-tool making and engineering arose in the same vicinity, consolidating the industrial belt.

On the eastern bridgehead, at Ballymacarrat, an industrial centre which had its genesis in a small iron foundry and a glass works now augments the great ship-building industry which was established at the head of Belfast Lough in the middle of the last century. A little further east the Connswater, flowing north into Belfast Lough, has attracted its share of industries, inertia again having played a part in their retention.

The map showing the land taken over by industry in Belfast sums up this important category of land-use (Fig. 1). This one is selected because it would have been impossible on this scale to have shown the many functions of a capital city, but I will be referring later to some of these other functions. The map emphasises the industrial west, which together with its associated small terrace housing has been carried as far as the Triassic slopes leading to the scarp. Ship building and its associated industries occupy an entire quadrant whose apex closely approaches the city centre. The map also distinguishes those areas where housing is predominantly of detached types: to the north, between the scarp and the sea, to the south along the Malone Ridge and to the east. These purely residential zones are all expanding, but it is significant that the zone is practically non-existent in the industrially dominated west.

Not shown on the map are the very familiar functions of the city centre, which is concerned almost entirely with retail and wholesale business and with commerce. A detailed analysis would show differentiation within these broad categories, such as the commercial activities of Waring Street, or the more select clothing shops which 
moved into the once fashionable residential Donegall Place. It is natural, too, that commerce has developed to the south of the City Hall, the site of the former White Linen Hall, where Belfast laid the foundation of its prosperity. The size of the commercial centre is, of course, indicative of Belfast's metropolitan role in Ulster, further emphasised by its administrative buildings. These last functions having increased only gradually; there is no civic centre-the seat of government is outside the city limits-but several groups of administrative buildings do add to the character of the city.

That is as much of the general physical framework of the city as can be attempted in a short paper-I will add a little detail about one region later - and now $I$ want to discuss very briefly one aspect of the distribution of population. Perhaps the best single social criterion of urban functions and their pattern is shown in the uneven distribution of the people, by varying densities of population (Fig. 2).

Revealing, as it does, social structure as well as spatial grouping, density of population can be used as the starting point of the study of the interaction of social groups with their total environment. We are not studying the density as an isolated phenomenon, but in so far as it is a part or a function of-and, therefore, reveals-this interaction. Density is the outcome of, and a factor in, the formation of a certain kind of urban physical environment. This is especially so in Belfast, where there are practically no flats ${ }^{5}$ to disturb the densities, so that two similar densities imply a similar urban environment. On this map an attempt has been made to make the index clearer by eliminating open spaces, large factories and bombed sites as far as possible before calculating densities. A high density, then, points socially to overcrowding in the lower classes, physically to endless rows of tiny kitchen houses or, sometimes, dilapidated, large houses taken over by several families. Light densities usually indicate middle class groups with a different family structure, physically they imply detached or semi-detached villas in a more spacious setting. This, of course, with the exception of the city centre, in which the permanent population is very small indeed. The map is based on the 1951 census figures for enumeration districts, giving a more detailed picture than has been possible before, and it reveals the following pattern :-

(1) The cantre of the eity is a relatively empty core; the real hub of day-time activities has practically no residences, as one would expect.

(2) Around this core is a zone in which densities vary from dense to very dense (100 to over 200 per acre). This zone is narrowest in the south and most extensive in the west, where the highest densities in Belfast are found.

(3) There are three areas of light density (under 50 per acre).

In the east there is a tendency towards a gradual zoning outwards: the other two areas are north and south. This zone is practically non-existent in the west.

This is a fairly close reflection of the map of industries and housing. The three regions of very light densities are those of detached housing where there are no industries. The factories are studded along the

5 The map is based on 1951 figures. Blocks of flats have been built since that date, but in 1951 the only considerable block of flats was outside the city boundary. 
crowded reaches of the Farset and the Forth. South of the city centre the Cromac district has long been associated with docking and with the gas works, and it is an area of dense population. In the closely packed streets north of the contre are dockers, spinners and other factory workers. In the east too there is a zone of heavy density around the industrial hub. In parenthesis I would like to note the difference in densities on either side of the Lisburn Road, as it is one of the indices of the sharp contrast between two regions which I shall be discussing later.

Age-sex pyramids would help to complete the picture. As one would expect there is a high proportion of children in the industrial west and immediately around the city centre. This tends to diminish, even in the west, except where recent housing estates on the outskirts upset the pattern. The size of the family is, of course, a primary consideration in allotting houses in such estates. In other directions the proportion of children falls, and in the north, east and south the pyramids in the residential areas are characterised by high proportions of persons of middle age and late-middle age, and by a very much lower proportion of children.

The first query is this. How does the pattern of population density in Belfast correspond to the theoretical patterns which human ecologists have evolved on the assumption that a city's growth and development obey cartain universal sociological or economic laws? The simplest of these schemes is the idealised pattern of concentric zones, faintly reminiscent of Aristotle's ideal city. The clearest statement of it was put forward by Burgess of Chicago in relation to the modern city, and he suggested five zones:- 6

(1) The business centre, which is emptied of people each evening.

(2) A zone of transition in which deteriorated property is used for retail shopping, rooming houses and low-rent tenements.

(3) A zone of workingmen's houses.

(4) A zone of middle-class houses, and

(5) A commuters' zone.

This scheme could be applied quite plausibly to East Belfast if we accept the business centre as being the other side of the river. The transition zone is very small, as the majority of the houses were built for shipyard workers. The zone of middle-class houses is well marked. Holywood and Dundonald, beyond the city boundary - and even Bangor-coms in the commuters' zone. This theory is based on an organic concept of growth and decay, so that differences in age and function tend to move from the centre to the periphery in concentric waves. Although the concept of differences in age as a consequence of growth (not necessarily of function) is generally accepted-and Burgess himself mentioned exceptions-the connection between it and the social groupings which are concomitant with the zones is not explained: it is implied that segments of society are impelled to move and to redistribute themselves in answer to the inevitable changes consequent upon growth and decay, a determinism which largely excludes human volition.

${ }^{6}$ Burgess, E. W., Proc. American Sociological Society, XVIII, 1929, pp. 88-89. 
Modifications of this pattern have been suggested by others. Brunhes 7 has emphasised the radial growth of towns, bringing into focus the significance of communications: and the American sociologist Hoyt has developed this to the point of substituting sectors for concentric zones, ${ }^{8}$ on the assumption that once differences-for example, of class of residences-bave been initiated around the city centre, they tend to move outward, radially, on to new land, due to their inability to move sideways into areas where land use is different. In this way a region of high rents moves in a sector towards the pariphery because it cannot move sideways into a region of low rents. We cannot pursue this theory in detail but, thinking in terms of residential classes for the moment, West Belfast seems as if it might fit into this concept. Rows of industrial workers' houses have spread west to the exclusion of upper-class houses, while the southern sector, which received such an impetus by the building of fine houses around the White Linen Hall in the early part of the 19th century, is markedly different and fairly uniform from near the centre to the periphery. But again in this theory the way in which each sector is built up is deterministic, and it is strange indeed if ecological determinism differs so much on either side of the Lagan that two parts of Belfast support two different idealised schemes.

Growth, of course, is complicated by function. It is difficult to deal with them separately, but often the latter imposes a pattern which the former follows. Any city's function is primarily economic. The traders' agora in Aristotle's city had to be on a site convenient for the collection of all goods sent from the country. The city is a point of collection, distribution and exchange. These functions are concentrated in the centre, where transport routes meet. From an economic point of view they occupy an area of $(a)$ high accessibility, and $(b)$ high land values. Outside lie residential areas which bave much lower land values.

It has been postulated that in function, then, there has been a sorting out, regulated by competition for this point of highest accessibility. ${ }^{9}$ This automatic selection is claimed by some to be the principle which underlies the pattern. I should remind you that the idealised patterns I mentioned previously did not concern themselves with causes but here is a regulating principle-the need for accessibility-which it is claimed determines even the location of working class homes and upper-class villas. For if a man can overcome the economic disability of having to pay for transport, if he owns a car for example, he can live well outside the city limits: if he is a factory hand he will live as near the factory as possible.

The centre being the point of highest accessibility, land values here will be high in the area occupied by retail and wholesale trading, and will decrease towards the periphery of the eity. This doesn't necessarily lead to a concentric pattern, because roads tend to take retail functions outwards and secondary centres arise.

I need hardly remind you that the implied sorting out process is

7 Brunhes, J., Human Geography, Chapter III, London, 1952.

${ }^{8}$ Hoyt, H., The Structure and Growth of Residential Neighbourhoods in American Cities. Washington, 1939.

- Firey, W., Land Use in Central Boston. Cambridge, 1947, p. 10. 
held to be quite mechanical, so that this theory is upheld by economic determinism.

It is with these broadly accepted theses in mind that I would like to examine further one sector of Belfast. Anything more would be quite beyond the scope of a short paper, so I will confine myself to South Belfast, west of the River Lagan. In dealing with this area we will bear in mind what seem to me to be the two major weaknesses in the theses which I have just outlined :-

(1) The first is that they operate on a two-dimensional plane. This is especially so with the selective economic processes arising from degrees of accessibility. Distance, according to this idea, is the only impediment to social interaction. If the earth's surface were a characterless plane, as this implies, the geographer would be superfluous. It may be significant, of course, that most of these theories of city structure were formulated in the Middle West, beginning in Chicago, where the natural landscape seems practically featureless, but I mustn't pursue this line of reasoning too far or I shall be guilty myself of the most blatant form of determinism ! But human ecologists there had no need to take physical irregularities into great account. There can be no doubt that elsewhere they must be dealt with. Moreover, they are not there to give irregularity to an idealised form, but they may well be the framework on which a city first takes shape.

(2) Secondly, these ecological and economic processes, operating automatically as they do, eliminate the human or cultural element. Is the cultural element to be a residual category? That is the ever-growing class to which awkward exceptions are usually relegated. Once again it should be remembered that the Middle West cities of the United States have grown rapidly, and are so recent that "cultural values "-often another term for "inertia" have had no time to accumulate, and a recent urgent disclaimer comes from Boston, ${ }^{10}$ a city in which cultural values had developed over a long period of time, and which is much more akin to our own cities and towns. Society is not mechanical, nor is the land use of a city determined mechanically. Cultural values must be assessed, and their role in forming the urban pattern decided.

These, then, are the two things to be kept in mind, and I will try to show to what extent they operate in South Belfast-the physical basis which might play a primary deciding role, and the cultural values around which we have to reassess deterministic economic principles.

Although we are primarily concerned with such a small sector, it would be as well to examine its physical basis in a wider context (Fig. $3 a$ ). We are dealing with a portion of the Lagan Valley between the river and the scarp of the Antrim platean. The valley floor, of

10 Firey, W. Land Use in Central Boston. 
sandstone overlain with glacial drift, is comparatively narrow. It gives way to the slope of Triassic marl which leads to the chalk and basalt of the steep scarp face which so dramatically overlooks Belfast. Immediately west of the city the scarp recedes in a wide col of about two and a half miles, in which the waters of the Milewater, Forth and Farset collect. From the south-west the Blackstaff follows approximately the pre-glacial course of the Lagan, running for the most part in the ill-drained alluvial flats called Bog Meadows. Between the Blackstaff and the Lagan sand and shingly gravel, washed from the retreating ice, formed the high tongue of land known as the Malone Ridge. This ridge is for the most part about 70 feet high, descending fairly sharply on the west, and very steeply on the east. Toward the centre of the modern city, where the rivers entered tidal waters, silts were laid down post-glacially. The water of the longh was then some 20 feet higher than now, and when the land emerged a considerable area of silt was revealed, contained by the prehistoric coast-line referred to above.

The way in which man utilised this area was largely decided at a comparatively early stage in. Belfast's history, and the map (Fig. 3b) summarises its use in the 1830 's. Much of the land west of the slob-land had by now been committed to industry. The rivers which had turned the first grist-mills now gave power to textile mills over a comparatively wide area. The Bog Meadows were avoided, but the dry, favoured gravel ridge which carried the Dublin road was occupied by prosperous English farmers, and later many elegant villas began to line the Malone Road.

Thus the framework of the land-use of the present city was foreshadowed by the use made in former times of land lying adjacent to the old town, and that, in turn, bore a simple, straightforward relationship to the physical environment.

We will now look at the modern land-use of that sector of Belfast south of the eity centre, lying between the Bog Meadows and the Lagin (Fig. 4). The classification has been reduced to the barest minimum in order to avoid confusing the main issues. Beginning south of the City Hall the sector excludes the main retail centre, but it does include a considerable area of warehousing, small manufacturing and offices, as well as the markets, concentrated at the former bridge-head. The railway from Dublin, making use of the level land skirting the Bog Meadows, limits the sector to the west.

Land-use concerned with retail shopping is of three kinds :-

(a) Where the building is used entirely for retail business or where it is combined with office use,

(b) Where the retail business is combined with a dwellinge.g., flats above shops, and

(c) Where the business is part only of a dwelling, and isolatede.g., the corner store and the parlour shop.

In this sector is one of the numerous secondary centres, of radiating roads of retail shopping only, which lie around the hub of Belfast. Professor Evans has pointed out that these tended to develop at the point where routes multiplied as the slob-land gave way to firmer ground." Peter's Hill is an example, and so is the region around Holywood Arches. There is a sharp contrast between Sandy Row,

11 Evans, E. E. Belfast, the Site and the City, Belfast, 1944. 
the old meandering entrance to the city, and the adjacent straight efficient streets laid out in the early 1800's and built up in the mid-19th century. Sandy Row retains its retail function, but in Dublin Road, for example, one can still see a group of dignified Georgian dwellings which show it to have been formerly residential. Many of the shops are adapted dwelling houses. Shaftesbury Square, with its five banks, is the hub, its retail functions diminishing along the roads radiating from its centre. Beyond this busy centre is the "green belt" of the 1850 's, a ring of institutions including a hospital, a school, collegesincluding Queen's University - and the Botanic Gardens. Beyond this again land-use is almost entirely residential. Any retail shopping here is combined with dwelling premises, but its distribution is peculiar. There is a small centre, with post office but no bank, on the loop road which serves Stranmillis. The Malone Road has no shops, two public houses alone representing the retail trade. The Lisburn Road is entirely different. This road became the new route to Dublin early in the 19th century, but there was little development along it or between it and the railway until very late in the century. Serving, as it does, the Lagan Valley, and with the modern emphasis on road transport, this is Belfast's busiest thoroughfare. It is lined on one side with shops, and has several subsidiary centres along it, with cinemas, banks and post offices. But its use as a main artery is not in itself sufficient to explain its contrast to the Malone Road, because it will be noticed that one side only busies itself with shopping. This point will be emphasised later.

Types of dwelling are also shown on this map. Although grouped rather arbitrarily on size, they do nevertheless indicate the different areas which stand out quite clearly. Within the railway branch loop, houses are almost uniformly small in what Burgess would call the zone of workingmen's houses, with many parlour shops studding the area. Other elements in this well defined urban environment are undesirable-the proximity of factories, overshadowing warehouses, and the overpowering presence of the gasworks. The physical environment is of a distinctive kind, and when it is brought alive it is to the sound of factory workers' boots, the clamour of children and the talking of shawled women. Immediately outside this is a zone of much bigger and more substantial houses formerly belonging to the upper middle-class. Some of them-such as those in University Square--are good examples of Georgian building. The society which produced them, enduring though the Victorians thought it, has changed: but their brickwork was good-if not beautiful-and modern society is left to adapt itself as best it can to the fashions of a former age. Most of the upper middle class families which once lived here have moved south to more modern villas, and the large terrace house has often suffered one of three fates. Many have become boarding houses - a map of the distribution of university students' lodgings shows that they are entirely within this zone. Some houses have become converted into flats. Many of the biggest houses have changed their function altogether, becoming schools, departments of the university or offices. This is particularly true of the apex between the Malone and Lisburn Roads, and of the area immediately north of the university. A half of University Square, probably the finest terrace of Georgian houses in Belfast, is now occupied by departments of the university. 
This is a region partly in transition, where respectability is often maintained at the expense of keeping boarders, and where there is a considerable shifting of population.

Beyond the "green belt" there are contrasts between the villas of the Malone Ridge and the very modest dwellings in the region between the Lisburn Road and the railway-this underlies the contrast referred to in the density map. In parenthesis, all these houses have one thing in common-in being uniformly brick-built they bear the stamp, at least, of their environment. But it is the contrast which needs to be stressed, and it is in the residential sectors of South Belfast that the idealised plans of the American ecologists break down and have to be re-examined. It is obvious that there are three regions-the Lisburn Road (a name which will indicate the region between the Lisburn Road and the railway), Malone and Stranmillis. The relationship between Stranmillis and the others must be left for another time-it is sufficient to point out that apart from one connecting street in the north and the fact that Stranmillis Road eventually joins the Malone Road, there is no physical connection between the two areas, and the social barrier is considerably strengthened.

Taking the differences between the first two, unlike the ridge itself, which slopes gradually from the Malone Road to the railway there is no even gradation in social values. The Malone region is comparatively uniform, and socially the Lisburn Road is a "precipice." This is illustrated clearly in the map of Poor Law Valuations (Fig. 5a). (Rents would have provided the ideal comparative data, but the majority of the Malone inhabitants are owner-occupiers.) Values are naturally lower in the terrace housing in the northern part of Malone, but, on the whole, they are well above $£ 50$. The well-marked exception on the Malone side of Lisburn Road is Cussick Street, a cul-de-sac of very small terrace housing. There is a very sudden drop to under $£ 20$ and, in some cases, to under $\mathfrak{1} 10$ when the Lisburn Road is crossed. Values are lower, too, in those parts of Malone in which the roads open on to the Lisburn Road only and in which the houses are smaller. Walking along a transverse road and into its continuation beyond the Lisburn Road, the abruptness of the change is startling. It can best be illustrated perhaps by quoting some of the occupations of the people in a "social cross-section." Among those in Adelaide Park, for example, is a director, a doctor, a solicitor, a professor, and Lady X, and five university lecturers. Adelaide Avenue, the continuation of Adelaide Park, houses four policemen, three enginedrivers, four insurance clerks, a boilermaker, and a warehouseman. In Malone there are 70 company directors and not a single labourer, and in the Lisburn Road area, 167 labourers. Yet there is no physical obstacle. Physically, it's true, the top of the ridge is far removed from Bog Meadows, but there is no significance in the point-about 40 feet-at which the social change takes place which makes two uniform and distinctive regions and which decides different social environments.

The social values behind the differences are emphasised in the map showing distribution by streets of children attending public elementary schools in Belfast (Fig. 5b). Although one of the factors here is a contrast in family structure, this is not as marked as one would expect. The age-sex pyramid for an enumeration district in the Lisburn Road area is compressed towards the base in much the same way as that 
in a Malone sample. The difference in density, it will be recalled, is fairly marked, between more than 50 per acre and less than 15 per acre. But allowing both for slight differences in family structure and for varying densities of population, it is apparent that social preferences predominate in this map, and the divide between education in a private as opposed to a public school is the Lisburn Road itself. Again one side only of the Lisburn Road is concerned largely with retail business: this is the railway side. That is, the Malone region is uniform up to the road itself. No divide could be sharper.

What determines such a difference? It is irrational according to the economic theory of accessibility and it is exceptional or residual in the concentric theory. The sector theory cannot entirely explain the long wedge of low value, because its base is not dissimilar to that of the Malone. What has preserved the Malone region and made it inviolate, and why are both regions comparatively uniform ?

In the first place, the physical framework-which is denied or overlooked in these theories-is important as far as the centre of each region is concerned. The desirability of the ridge-top for residential use goes without saying, as well as the undesirability of being too near Bog Meadows. But that is not the only explanation of the two regions to-day. People do not necessarily check the nature of the subsoil when moving into a new district: if their economic progress has been favourable they move into what estate agents call "a select residential district". And the Malone area was thought of as such long before it was included within the town boundary. It boasted villas and prosperous farms-it was a "pleasant parkland" in the 1820 's and $1830^{\prime} \mathrm{s}^{12}$ its social character already defined. When the new-rich industrialists were rapidly increasing in the latter half of the 19 th rentury and moving to more expansive suburbs they found here a region where social values were already fixed. This is very different from a rapidly growing Middle-West town which normally expanded into territory which was culturally neutral. By 1870 Malone was studded with villas, but the Lisburn Road had attracted very little housing. The new road was built in the 1830 's, but it was very slow in attracting settlement. When pressure arose in the phenomenal late Victorian population increases, and land was needed for working. class housing, the owners of the ridge land were careful to preserve their social value as far as the new road, and to permit terrace housing only beyond it. Later building in the Malone area largely preserved its character. Population pressure filled the Lisburn Road gap mainly with working-class houses. During the same period expansion in North Belfast was negligible, and expansion west consisted solely of bye-law housing.

Another factor lay behind this southward trend of upper-class residences. The basic social pattern of Belfast was set in the late 18th century, when the west was abandoned to industry and when upper middle class houses became a cluster south of the city centre and near the new White Linen Hall. The spacious planning around the Linen Hall and the Academical Institution accentuated this. Distribution maps of occupations in the 1830's show that immediately around the Linen Hall were the town houses of the gentry-the

12 See references in Houses of Gentry in Benn, G.: History of the Town of Belfast. Belfast, 1823. Also directories of this period. 
Chichesters, the Downshire families, the Earl of Masserene and Sir Stephen May, and here, too, lived most of the magistrates and doctors. The houses were spacious, many having 15 bedrooms, and most of them being rented at between $£ 50$ and $£ 100$ per annum. This was very different from housing in the west and north, where people crowded into two or even one bedroomed houses and paid rents

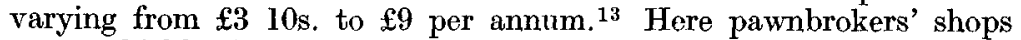
are as thickly distributed as surgeons' houses are in the south. The social distinction between South Belfast and the remainder is clear. When roads were constructed as alternatives to Sandy Row, the rich followed these, and vestiges of their terraces can still be seen. Eventually the Malone was reached and its character confirmed. Social values now became almost a fetish, the word "Malone" jtself becoming sufficient to indicate a certain section of society. This description might seem to fit Hoyt's expanding sector were it not for one important fact. In American cities, which rapidly expanded into social vacua, the sector determines its own social value as it grows. South Belfast expanded mainly into a region already known as "select": its social values were pre-determined.

We can now turn to the initial criticism of ecological theory, the ignoring of the initial physical basis-the landscape-and the preoccupation with economic to the exclusion of social values.

The 19th century growth which took Belfast beyond the slob-lands was no expansion on a two-dimensional surface. Physical amenities and disabilities lay in its path, to be utilised, avoided or overcome. This initial impulse has, to a large extent, been preserved in presentday regions, by inertia. I say "preserved" because it need not necessarily account for later accretions or be taken as the deciding factor in to-day's pattern. Initial impulses, though governed by the landscape, can give rise to a chain of reaction which is social. To understand its origin we must go back to the physical, although to understand the regions to-day we must understand cultural factors.

Social values were substituted for physical advantages many decades ago in Malone, and to-day they decide the social character and residential land-use in South Beifast.

We now come to the second point : in so far as the social values of surrounding districts were largely determined by previous land-use before the city itself expanded and brought these districts within the boundaries, economic causation cannot uniformly determine land values in relation to degrees of accessibility--the difference between the Malone Road and the Lisburn Road is too great and too significant to be in a residual category. Even along the Lisburn Road itself, which one would expect to show economic gradation, values differ on either side of the road. Here is a pointer that social values should be fully explored as possible determining factors in land-use and in forming urban regions. Seeing that social value, in this case, is itself the outcome of the interaction of physical and social environments, its significance must be far-reaching.

${ }^{13}$ Monaghan, J. J. Social and Economic History of Belfast, 1801-1825. Unpublished Ph.D. thesis (1940), Q.U.B. 
I have merely touched upon some of the many problems which the social geography of Belfast reveals, but it may have been enough to show that in this field of study not only must the physical background be examined, and the part played by it in the initial fashioning of the city understood, but the cultural factors and, more particularly, the social values set on land and localities must be explored before we are nearer to understanding the complex interactions which give us the regions of to-day.

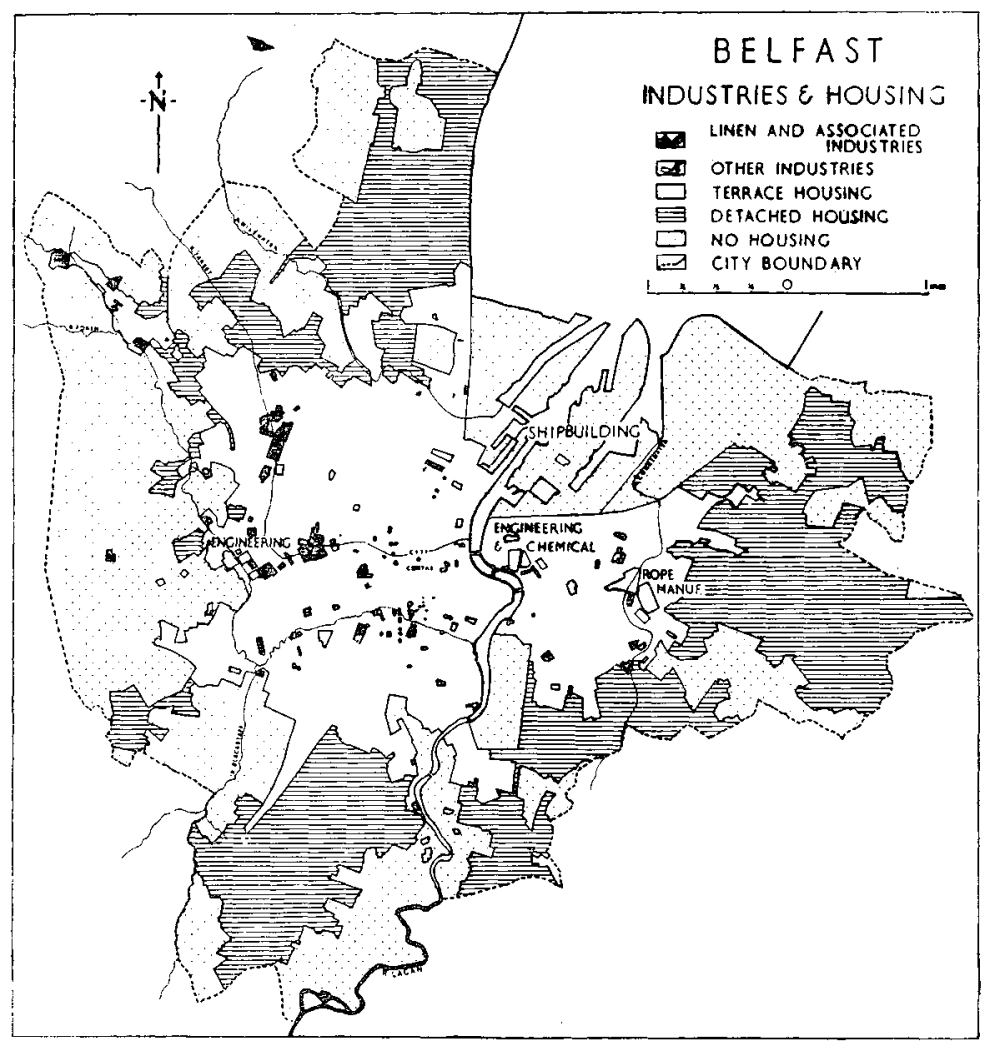

Fra. 1.-Distribution of Industries in Belfast, 1951. 


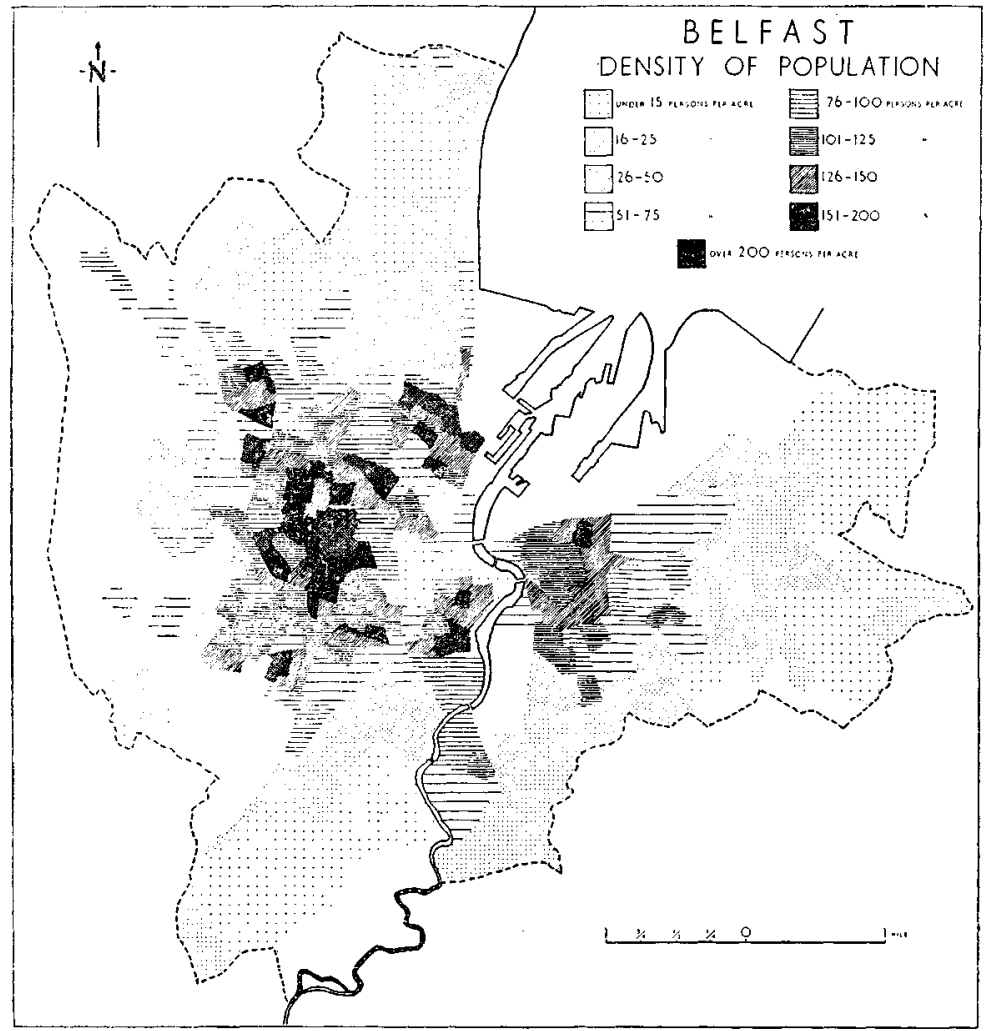

Fig. 2.-Density of Population in Belfast, 1951.
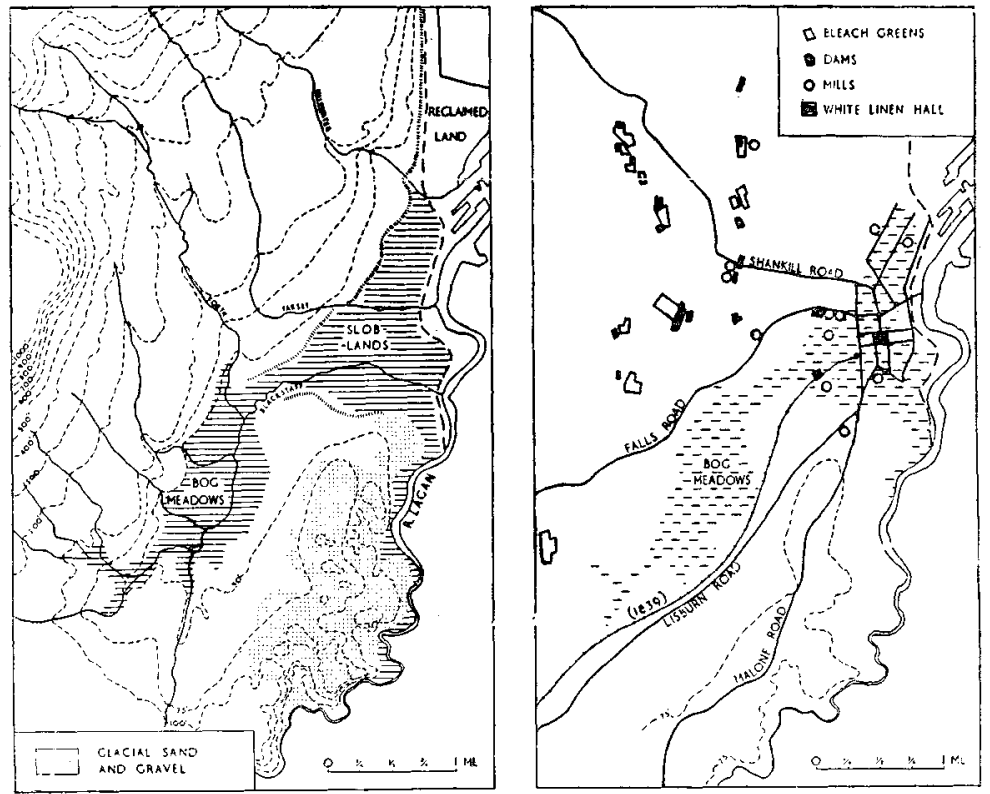

FIG. 3. (a) Physical geographical basis of West and South Belfast. (b) - Industrial land. use in West Belfast in 1839. 


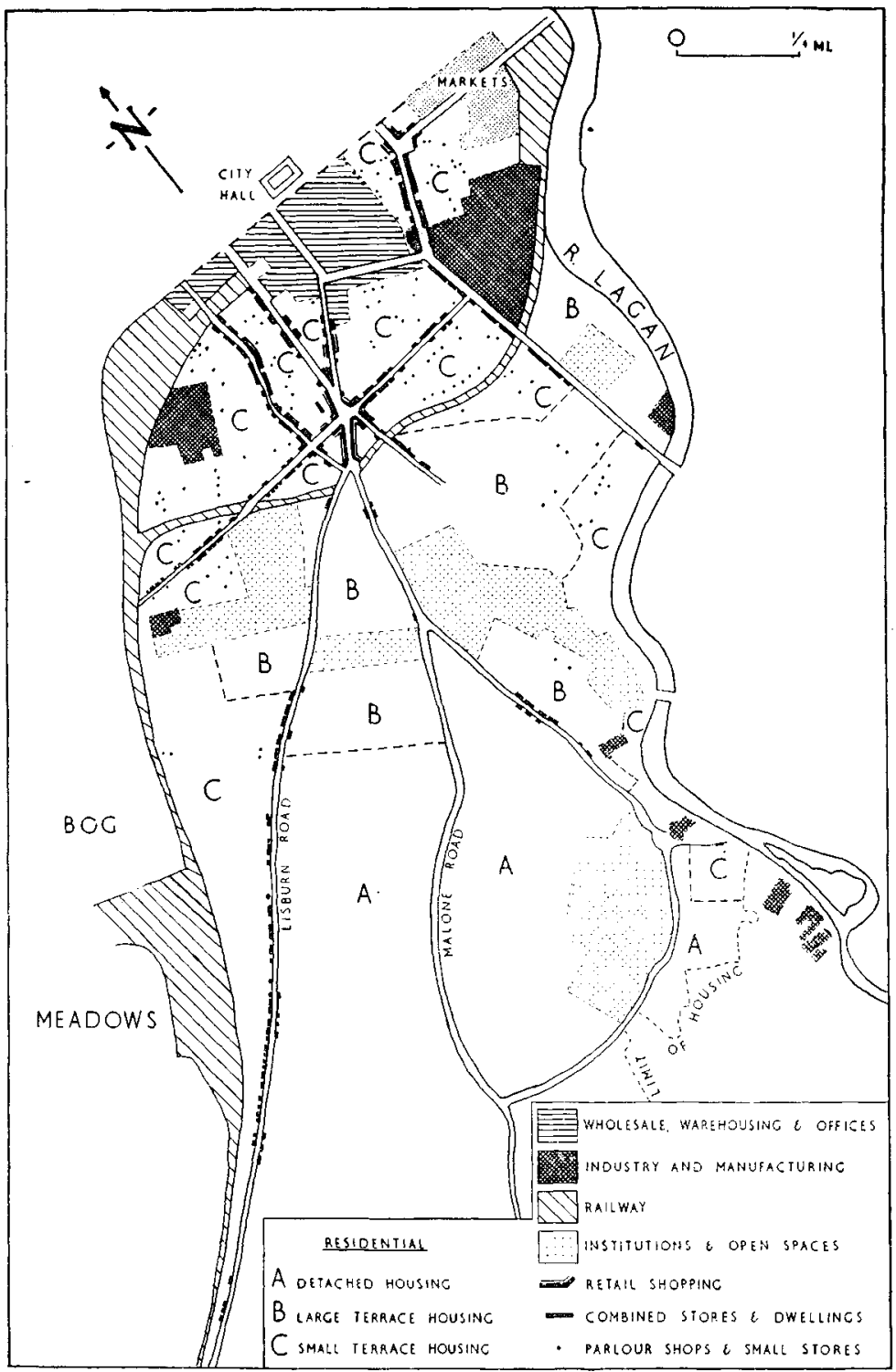

SOUTH BELFAST - LAND USE

Fia. 4.-Land-use in South Belfast. 


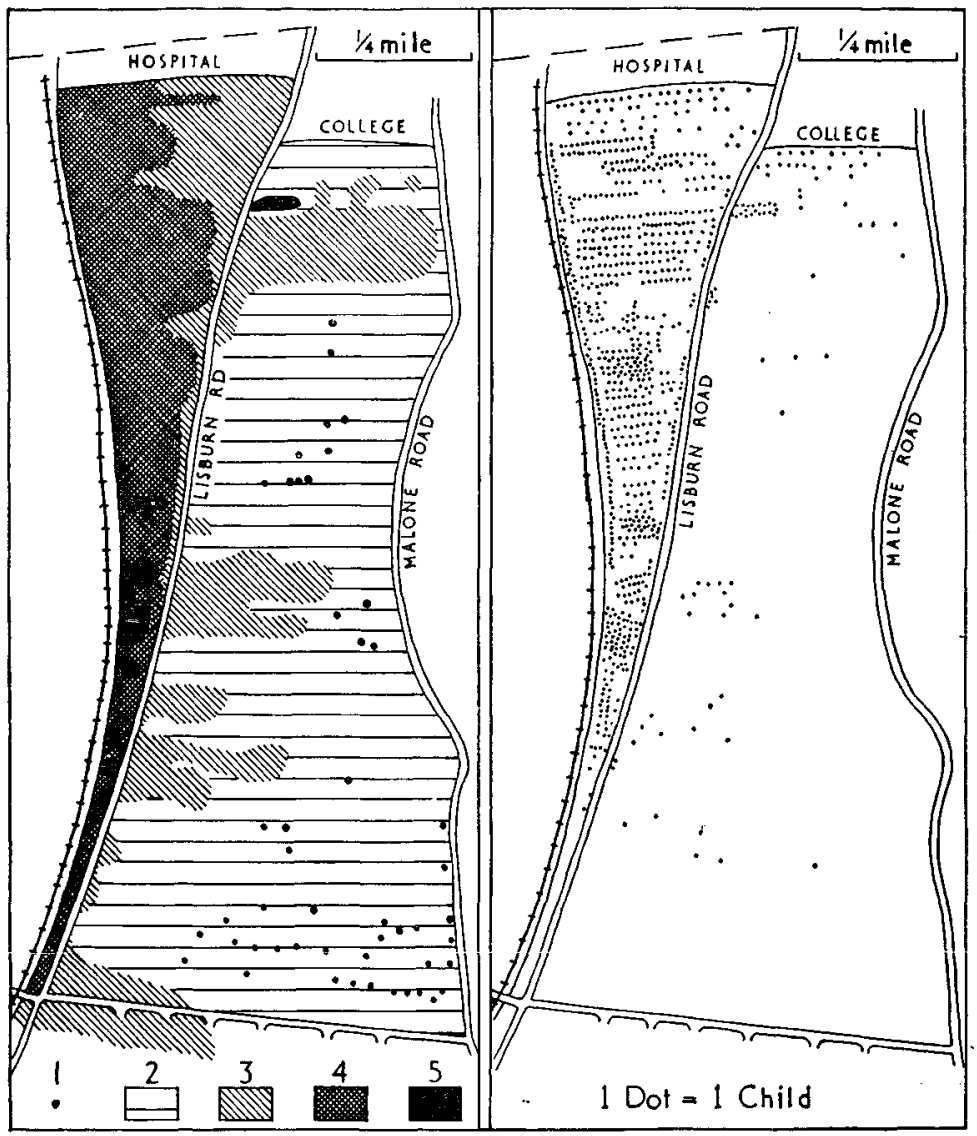

FIG. $5(a)$.-Dwelling-house valuations in part of South Belfast:

$1=$ over $£ 100$ p.a. ; $2=£ 51-£ 100 ; 3=£ 21-£ 50$;

$4=£ 11-£ 20 ; 5=£ 10$ and under.

(b).-Distribution of Public Elementary School children in part of South Belfast.

\section{DISCUSSION}

I should like first of all to thank the members of the Society for having invited me to the meeting this evening to hear a most interesting paper, upon which I congratulate Dr. Jones. Speaking as a townplanner, I find that the paper has given me much to think about: in particular, it emphasises one matter which is of great importance to planners : that is, the way in which a big city is continually changing. Indeed, if Dr. Jones had sought a different title for his paper, he might have called it "The Changing City."

Now I think it would be true to say that this conception of the city as a place which is constantly changing is comparatively new, at any rate in the field of town planning. I am referring to the built-up 
centres, of course, and not to the expansion of cities by new building on the outskirts. The planners of the Renaissance, for instance, tended to regard the settlements which they designed as finite works of art. They gave them a strongly emphasised geometrical pattern and obviously considered that once built, they would remain unchanged, at any rate for a long period.

And in more recent times, we find Sir Ebenezer Howard regarding the large city with dismay. He considered it a most unsatisfactory place in which to live and work, but the remedy he proposed was not the reconstruction of the city itself, but the building of new garden townships well away from the big existing centres of population. Indeed, the first town-planning Acts passed in England only gave powers to local authorities to prepare schemes for lands in course of development, or which were likely to be developed in the near future. They made no provision for the replanning of existing builtup areas.

Appreciation of the fact that the replanning and redevelopment of existing cities was not an impossible task came gradually and it was not until 1932 that an Act was passed to make provision for this. It was at last realised that a great city is always in process of gradual reconstruction; it has been pointed out, for instance, that most of Manchester has been built or rebuilt during the present century. Planners saw that advantage might be taken of this gradual reconstruction to replan city centres and to make them more pleasant, convenient and healthy places in which to live and work. To-day, plans for the redevelopment of all the large cities of Great Britain are being prepared, or are in process of being executed.

But, as Dr. Jones has pointed out, the changes that take place in the city aren't confined to the rebuilding of old structures. The use of buildings and the use of land change, toc. He has also drawn attention to the fact that the influences-geographical, economic, mechanical and cultural-which shape a city and cause rhanges to take place in its structure, are themselves also subject to change. It is obvious, therefore, that the planning of a city is very different from the planning of a house, which in most cases occurs only once in the life of the building. In the city the need for planning is continuous.

It will be appreciated that this constant change in city structure presents the planner with many problems. Dr. Jones has referred to the changes which have been taking place in the district around the University. It is obvious that such changes can greatly affect the character of a district, even if little rebuilding takes place. A change of this kind in the character of one district may also affect other parts of the city. For instance, if the character of a district changes from residential to commercial, or industrial, traffic problems may arise. The kind of traffic in the area will be different from before ; there will be more lorries and vans, and the volume, too, will probably increase. The flow of traffic to and from the district may affect neighbouring districts and congestion and bottlenecks may be caused at places some distance away. This is only one example of the way in which a change of use in one part of the city may react on other parts.

It will be necessary, therefore, to consider how these forces which operate to alter a city's morphology should be guided and controlled. 
On the one hand, the planner must endeavour to protect the amen. ities of pleasant residential areas and to prevent changes from taking place in parts of a city where these may give rise to difficult problems of the kind to which I have referred. On the other hand, it is necessary to ensure that the development and prosperity of the city are not retarded by restrictions, for one of the functions of good planning should be to promote economic prosperity. I should very much like to hear Dr. Jones' views on these aspects of city planning.

There are other matters in the paper on which I should like to comment, but time is getting on and no doubt some of these will be dealt with by other speakers. I shall therefore conclude by proposing a very hearty vote of thanks to Dr. Jones for this very interesting paper, which I am sure we have all enjoyed.

Gilbert Camblin

The vote of thanks was seconded by Mr. D. G. Neill. 